\title{
THE STUDY ON ADDITIONAL CRIMINAL IMPOSITION THROUGH COUNSELING COMPLIANCE IN DOMESTIC VIOLENCE CRIME
}

\author{
Simplexius Asa ${ }^{\boxplus}$ \\ 1 University of Nusa Cendana, Kupang, Indonesia \\ $\bowtie$ asasimplexius@yahoo.co,
}

\section{CITED AS}

Asa, S. (2021). The Study on Additional Criminal Imposition Through Counseling Compliance in Domestic Violence Crime. Journal of Law and Legal Reform, 2(4), 553-568. https://doi.org/10.15294/jllr.v2i4.48113

\section{Submitted: December 7, $2020 \quad$ Revised: March 11, $2021 \quad$ Accepted: July 11, 2021}

\section{ABSTRACT}

The Domestic Violence Law stipulates an alternative for judges to impose additional penalties in the form of referrals for counseling aiming at providing protection to victims, either as preventive measures or preventive ones. There are three important principles that should frame the assistance provided to the victims by the law enforcers, health workers, social workers, companion volunteers, and spiritual counselors namely: (1) protection to the victims, (2) Sensitivity to the interests of the household, (3) leads to household unity and harmony. This research is designed as a normative research based on documentary research, while the analysis of the collected data is carried out and presented in a qualitative-descriptive manner. This study concludes three important things. First, additional punishment in the form of orders for 
perpetrators of domestic violence crimes to attend counseling so that the perpetrators can be aware of their actions and willing to change not to commit acts of violence again. Second, the implementation of counselling the perpetrators of domestic violence should take into consideration judicial and sociological requirements when providing counselling as an additional penalty in the form of orders. Third, study finds that attending counseling benefits the family in maintaining the unity of the family and that the children can be raised in a more conducive atmosphere. The weakness of the approach is that the process is time consuming and requires the deployment of more resources.

Keywords: additional penalty; counseling, domestic violence.

\section{INTRODUCTION}

In cases of Domestic Violence, the main victims are women and children that requires special attention and treatment. The reality today is that cases of violence against women and children do not only occur in the public sphere, but also in the household as private sphere. In one hand, domestic violence in some of its gradations is a criminal act which therefore requires punishment, but on the other hand it is also necessary to consider the position of the perpetrator as part of the integrity of the family which is the smallest community in the life of society, nation, and state.

Law Number 23 of 2004 concerning Domestic Violence (UU KDRT) has mentioned and categorized forms of violence that include domestic violence into four categories, namely:

1. Article 6 of the Domestic Violence Law concerning physical violence, namely acts that cause pain, fall ill or seriously injured.

2. Article 7 of the Domestic Violence Law concerning psychological violence, namely acts that result in fear, loss of self-confidence, loss of ability to act, feelings of helplessness and/or severe psychological suffering.

3. Article 9 of the Domestic Violence Law concerning sexual violence, namely forcing sexual relations carried out against people who live within the scope of the household, including forcing sexual relations against one person within the scope of his household with another person for commercial purposes or certain purposes. 
4. Article 9 of the Domestic Violence Law concerning household neglect, namely the act of neglecting people within the household, even though according to the law that applies to him or because of an agreement or agreement he is obliged to provide livelihood, care or maintenance to that person, including the actions of any person that results in economic dependence by limiting or prohibiting proper work inside or outside the home, so that the victim is under the control of that person.

Further, regarding the four categories of domestic violence, the Domestic Violence Law is also expressly and regulated in Chapter VII with the title Criminal Provisions. The criminal system that is regulated is an alternative criminal, consisting of two choices, namely imprisonment or fines. The alternative criminal and criminal system as referred to here, in its implementation implies that the judge only chooses one of the two available options.

The main crimes regulated in the Domestic Violence Law consist of two versions, namely:

1. The first version, regulated in several provisions, namely Article 44, Article 45 and Article 46 adopts a general maximum criminal determination system in which the legislators only stipulate the maximum limit of the sentence imposed. The maximum imprisonment which is regulated under the general maximum system is imprisonment for a period of 15 (fifteen) years, while the maximum fine is determined according to the general maximum system of $\mathrm{Rp}$. $36,000,000$ (thirty-six million rupiah).

2. The second version is the provision in the Domestic Violence Law which adheres to a special minimum and maximum criminal determination system, in which the lawmakers have set a minimum (lower limit) and maximum (upper limit) limit of the sentence imposed by a judge. This provision can be found in Article 47 and Article 48 of the Domestic Violence Law.

In the Domestic Violence Law, especially in Article 50, an alternative has also been set for judges to impose additional penalties in the form of referrals for counseling. In the general explanation of the law, the spirit (originally intend) is taken as a reference for judges in imposing additional penalties/punishments, namely primarily as an effort to provide protection to victims, both preventive and repressive. There are three important things, namely that law enforcers, heath workers, social workers, volunteers, and spiritual counselors need to: (1) protect victims, (2) be sensitive to household interests, (3) lead to household unity and harmony. More details can be quoted as follows: "responsive to the interests of the household which from the beginning was directed at the unity and harmony of the household." 
Specifically, regarding additional penalties/criminals for perpetrators who commit criminal acts, it is regulated in the provisions of Article 50 of the Domestic Violence Law, namely:

a. Restrictions on the movement of the perpetrator, both aimed at keeping the perpetrator away from the victim within a certain distance and time or limiting certain rights of the perpetrator as stipulated in Article 50 paragraph (1);

b. Determination of perpetrators to participate in counseling programs under the supervision of certain institutions, as stated in Article 50 paragraph (2). Regarding the provisions of letter $b$, it is emphasized in the explanation of the Domestic Violence Law, that what is meant by "certain institutions" are institutions that have been accredited to provide counseling services for perpetrators. For example, hospitals, clinics, counselor groups, or those with expertise in providing counseling for perpetrators for a certain period of time. This provision is intended to give freedom to judges so that they can impose a probationary sentence with a view to providing guidance to the perpetrator and maintaining the integrity of the household.

The general guideline in imposing a decision containing a sentence is that the judge is obliged to impose one of the main penalties (imprisonment or a fine) plus one or two additional penalties available. It appears briefly from the provisions of Article 50 of the Domestic Violence Law above that the provisions of letter a are more aimed at perpetrators of serious domestic violence crimes, which are very dangerous to the victim. In such case, the Judge needs to impose two additional sentences at once. While the provisions of letter $b$, are more aimed at perpetrators of domestic violence crimes that endanger the lives of family members but need psycho-social therapy to help change behavior that leads to improving the perpetrator's inner atmosphere and repentance as well as intentions and promises not to repeat the actions they have done. Here it appears that the guidance for the perpetrators is directed so that they can (re)maintain the integrity of the household.

On the one hand, practical experience so far has shown that domestic violence is an early indication and a threat to family integrity. On the other hand, the family is recognized as occupying a strategic position because it is the smallest unit of society which then develops into a larger community until finally forming the society of a nation, in other words, the family is the foundation of the nation's society. Efforts to form, develop, maintain, and prosper the family are efforts to maintain the community of a nation. The understanding that the family 
occupies a strategic position in building a civilized nation is taught, even commanded in religion.

Kupang is one of the developing cities in Indonesia and has become a barometer of urban development in NTT. Kupang is a city located in the southernmost region of Indonesia as well as the capital of the province of NTT. The majority of the population is Christian 85 (\%), both Protestant 50 (\%) and Catholic 35 (\%). Christianity generally discourages (even forbids) divorce. In this case, intensive and continuous counseling plus assistance and trauma healing are non-negotiable to maintain the integrity of the family.

According to Kupang City Criminal Investigation Unit Head, IPDA Boby J. Mooy Nafi, SH., MSi, every year there are no less than $100-125$ cases of violence reported, an average of $25 \%$ of which are domestic violence cases. From various sources and estimation results, it is estimated that the number of domestic violence cases reported to the Police is only $5 \%$ of the facts that were occurred in the community. Women only decide to report to the Police if they have suffered serious physical injuries and or because the neglect by their partners has caused prolonged suffering. Data on domestic violence cases collected at the Kupang City Police Resort as shown on Table 1.

Table $1 \sum$ Domestic violence cases reported to the City Police of Kupang in the last 3 years

\begin{tabular}{|c|c|c|c|c|c|}
\hline \multirow[b]{2}{*}{ No } & \multirow[b]{2}{*}{ Year } & \multirow[b]{2}{*}{ Case type } & \multirow{2}{*}{$\sum$} & \multicolumn{2}{|c|}{ Case Status } \\
\hline & & & & $\begin{array}{c}\sum / \% \\
\text { Revoked }\end{array}$ & $\begin{array}{c}\sum / \% \\
\text { Forwarded }\end{array}$ \\
\hline \multirow[t]{2}{*}{1} & 2017 & Physical Violence & 32 & $29 / 90,63 \%$ & $3 / 9.37 \%$ \\
\hline & & $\begin{array}{c}\text { Non-Physical Violence } \\
\text { (Abandonment) }\end{array}$ & 11 & $10 / 90,91 \%$ & $1 / 9.09 \%$ \\
\hline \multirow[t]{2}{*}{2} & 2018 & Physical Violence & 35 & 29 / 82.86\% & 6/17.14\% \\
\hline & & $\begin{array}{c}\text { Non-Physical Violence } \\
\text { (Abandonment) }\end{array}$ & 7 & $6 / 85.71$ & $1 / 14.29 \%$ \\
\hline \multirow[t]{2}{*}{3} & 2019 & Physical Violence & 30 & $28 / 93.33 \%$ & 2 / 6.67\% \\
\hline & & $\begin{array}{c}\text { Non-Physical Violence } \\
\text { (Abandonment) }\end{array}$ & 12 & $9 / 75.00 \%$ & $3 / 25.00 \%$ \\
\hline \multirow[t]{2}{*}{4} & 2020 & Physical Violence & 17 & 15 / 88.24\% & 2 / 11.76\% \\
\hline & (June) & $\begin{array}{c}\text { Non-Physical Violence } \\
\text { (Abandonment) }\end{array}$ & 8 & $6 / 75.00$ & 2 / $25.00 \%$ \\
\hline
\end{tabular}

Source: Kupang City Police's Domestic Violence Cases Data: 2017-2020

The data above shows that every year on average 80-85 (\%) cases of domestic violence that have been reported to the Police (Kupang City Resort) are 
revoked by the (Reporter/Victim). Field studies identify and confirm several basic reasons, including: (1) Victims do not want cases of domestic violence to be known to the public, usually because victims perceive that reporting to the authorities will only prolong the family disgrace; (2) The victim does not want to have too long to deal with/with the police; and (3) the victim on the one hand only wants that there is a lesson to the perpetrator while on the other hand he wants the case to be resolved immediately, there is no need to go through a lengthy legal process and so that the perpetrator (who is the victim's husband) can immediately return to life. household/family.

The facts above actually confirm the opinion that has long been believed to be true that domestic violence has its own characteristics, namely where the victim is dependent on the perpetrator. Further on the characteristics of domestic violence, Lidwina Inge Nurcahyo \& Choky R. Ramadhan stated:

"The issue of violence against women was born from the inequality of power relations between men and women in the household scope. Unequal power relations are one of the roots of violence against women. Inequality is exacerbated when one party has more control over the victim. This control is formed because of mastery over knowledge resources, economy, and also public acceptance (social status/social modality)".

The study conducted by Moerti Hadiati Soeroso identified several triggering factors for perpetrators of domestic violence such as financial problems, jealousy, child problems, parent problems, sibling problems, politeness problems, past problems, misunderstanding problems, problems not cooking, and husband wants to win alone. As a result, not only the wife but also the children suffer.

It seems that cases of domestic violence do not only have special characteristics but also require special attention, handling and treatment. As initial data, the following is presented the decision of the Rote Ndao Court in the Domestic Violence Case, namely Court Decision Number 41/Pid.Sus/2015/PN.Rno dated 20-01-2016 which has permanent legal force where the defendant is brought to trial for violating the provisions Article 44 paragraph (1) of the Domestic Violence Law Number 23 of 2004. The ruling in question basically states: 
1) The defendant Richy Ronaldo Kameo has been legally and convincingly proven guilty of committing a crime: committing a crime of physical violence in the household;

2) Sentencing the defendant Yudhi Hariyanto Bin Subiyantoro, therefore, with imprisonment for 6 (six) months;

3) Determine that the period of detention that the defendant has served is deducted entirely from the sentence imposed;

4) Determine that the defendant remains in custody;

5) Charge the defendant a court fee of Rp. 2,000. (two thousand rupiah);

Referring to the decision quoted above, it is clear that although it contains a sacred intention, namely to provide the main place for saving families and/or households, the provisions of Article 50 of the Domestic Violence Act have not been or have not been (ever) considered and implemented through a judge's decision. Many obstacles can be identified as causes, including: the unavailability of adequate counseling services; the unavailability of the number of professional counselors who can provide certain counseling services according to the needs of perpetrators of domestic violence crimes; unavailability of a referral system; and so forth.

\section{METHOD}

The research is designed as normative research based on a documentary research, while the analysis of the collected data is carried out and presented in a qualitative-descriptive manner. The main source of data needed in the study is court decisions on domestic violence cases combined with library materials obtained from existing literature searches such as journals, published research reports and literature. Furthermore, to enrich the findings in the study, primary data was collected through interviews (interviews) and/or in-depth interviews with resource persons/informants (interviewees).

Theoretically, document study is also referred to as literature review, which is a study based on existing documents in the form of written library materials, as well as non-library materials in the form of recordings, virtual forms, and films. Creswell added that the documents referred to include public documents such as minutes of meetings and newspapers and discussions via email.

In this study, data collection activities are carried out to obtain and collect secondary data or legal materials, consisting of primary legal materials in the 
form of laws and regulations related to domestic violence, both those that have been in effect and those currently in force in Indonesia as well as secondary legal materials in the form of research reports, writings from experts both in the literature and published through journals. Some of the data collected is then processed and/or adapted before being presented. Secondary legal materials are also obtained through internet searches ( $w w w$ ), local, national, and international magazines and newspapers.

To support the data obtained from documentary research, primary data collection was also carried out through interviews (interviews) and/or in-depth interviews (qualitative interviews) with selected and determined policy makers to be interviewed (interviewees) as resource persons (informants). Interviews in qualitative studies are intended to obtain in-depth information about the research topic.

\section{THE IMPOSITION OF OBLIGATION OF COUNSELING IN THE RULLING OF DOMESTIC VIOLENCE CRIME}

The order for perpetrators of criminal acts to take part in a counseling program is included in the judge's decision when ending the handling of a domestic violence case. The true verdict is a final statement containing conclusions about all the facts obtained through evidence. The final conclusion of the judge consists of three types/choice of decisions. First, a decision containing a sentence (Dutch: veroordeling) is a decision that is handed down if the Court is of the opinion that the defendant is guilty of committing a crime as charged to him. Second, a decision containing acquittal (Dutch: vrijspraak) is a decision that is handed down if the Court is of the opinion that from the results of the examination at trial, it turns out that the guilt of the defendant as charged against him is not legally and convincingly proven. Third, the decision that contains the release of all lawsuits (Dutch: ontslaag van alle rechtsvervolging) is a decision that is handed down if the Court is of the opinion that the act charged with the defendant is proven, but the act does not constitute a criminal act.

Regarding domestic violence where the perpetrator was given an order in the form of a sentence, it is possible for the Judge to also impose additional punishment in the form of an order to follow counseling for the recovery of psychological conditions. This institution is still relatively new so that in its implementation there are obstacles and obstacles, 
Additional crimes that are oriented towards restoring the psychological condition of domestic violence perpetrators are becoming known and experiencing rapid development through therapeutic jurisprudence which since and in the last three decades has greatly influenced the development of philosophy and/or legal theory related to the study of social behavior, psychology, and mental health.

In several countries, such as Australia, New Zealand, and the United States, they have operationalized and institutionalized orders for counseling through the Family Court. The Family Court is actually a kind of pre-trial institution, or a preliminary trial before the actual court process takes place. Through the mechanism of the Family Court as an institution that conducts a preliminary examination, the risk of imposing a more severe and serious criminal offense can be avoided, unless the counseling program fails and/or cannot be fulfilled completely by the perpetrator.

Taking into account the main benefit of the regulation and imposition of additional criminal offenses in domestic violence in the form of an order to take part in counseling both family counseling programs and/or specifically counseling for perpetrators of domestic violence, it is deemed necessary to carry out a research that generally aims to gain perspective, knowledge and insight as well as learn best-practice in the field of counseling for suspects, defendants and convicts/convicts of domestic violence. The results of the study are expected to be used as guidelines for Law Enforcement Officials in the Integrated Criminal Justice System, more specifically for judges in imposing additional penalties for perpetrators. On the other hand, directly or indirectly, it is a juridical effort that can be done to maximize the protection of victims, especially paying attention to the integrity and harmony of their household.

Based on the description of the background and the statement of the problem above, the research questions set out in this study are:

1. Why is the additional punishment in the form of an order for perpetrators of domestic violence crimes to follow the counseling stipulated in the law?

2. What are the requirements that must be met so that additional penalties in the form of orders to follow counseling for perpetrators of domestic violence can be implemented?

3. What are the advantages and disadvantages of additional penalties in the form of orders for perpetrators of domestic violence crimes to follow counseling? 
As is well known, Law Number 23 of 2004 concerning Domestic Violence regulates in Chapter VII with the title Criminal Provisions, especially in Article 50 which stipulates alternatives for judges to impose additional penalties in the form of referrals for counseling. In the general explanation of the Domestic Violence Law, the spirit (originally intend) becomes a reference for judges in imposing additional criminal/punishments, namely primarily as an effort to provide protection to victims, both preventive and repressive. There are three important things, namely that law enforcers, heath workers, social workers, volunteers, and spiritual counselors need to: (1) protect victims, (2) be sensitive to household interests, (3) lead to household unity and harmony.

\section{THEORETICAL AND PHILOSOPHICAL STUDY OF COUNSELING AS ADDITIONAL SANCTION ON DOMESTIC VIOLENCE CASES}

Therapeutic jurisprudence is a school of thought in philosophy and legal science that developed along with social science in general and behavioral science in particular, based on the assumption that everything that comes from judges, whether actions in various ways and forms, words and/or orders that are ordered judges can greatly influence someone who is facing an examination in a courtroom, both psychologically and physically. Based on this assumption, it is deemed necessary to creatively develop a legal function that contains therapeutic value through judges, but without violating the juridical rules and/or values that are generally adopted by judges in court. Regarding the above, Winick and Wexler in an article entitled "Judging in a Therapeutic Key: Therapeutic Jurisprudence and the Courts," stated: Therapeutic jurisprudence proposes that we use the tools of the behavioral science to study the therapeutic and anti-therapeutic impact of the law and that we think creatively about improving the therapeutic functioning of the law without violating other important values, such as ... due process concerns.

Still in line with the views of Winick and Wexler regarding therapeutic jurisprudence as above, Anleu and Mack stated, $A$ therapeutic jurisprudence approach can also involve the courts or judicial officers working more closely with human services personnel to address various social and personal problems, including drug-abuse and addiction, homelessness, unemployment and lack of works - related and parenting skills. This demonstrates the legal system's interest in 
and engagement with the antecedent causes of crime or behavior that with in a person's court appearance.

It should be underlined once again that the purpose of this study is to study the functionalization and functionality of the mechanisms (processes and procedures as well as steps) and counseling programs/activities carried out by Law Enforcement Officials in case Judges (but including Investigators and Public Prosecutors in Integrated Criminal Justice System). The expected results are the availability of best practice data (strengths and weaknesses, advantages and disadvantages, advantages and disadvantages), programs and activities, processes and procedures as well as regulations related to the implementation of counseling provided by Law Enforcement Officials to perpetrators of domestic violence crimes on the one hand and maximum efforts are made to provide protection to victims, with particular attention to the integrity and harmony of their household.

Additional punishment in the form of orders for perpetrators of domestic violence crimes to attend counseling is intended so that the perpetrators can realize their actions, repent and or promise not to commit / commit violence again and the return of harmonious relationships with their wives and children in order to achieve the ideals of marriage promised before witnesses and priests / priests at the time of making sacred marriage vows and receiving the sacrament of marriage in the Church.

\section{ADDITIONAL CRIMINAL CONDITIONS IN THE FORM OF COUNSELING}

The additional criminal imposition in the form of an order to follow counseling, although it contains the intention to save the family, but in its implementation and enforcement requires several mandatory tools. During the study carried out in Kupang City, no data and facts were found that lead to the fulfillment of software and hardware to implement the judge's decision which imposed additional penalties in the form of orders to follow counseling.

The software in question, such as the number of trained counselors who are registered and registered as well as having academic competence and juridical competence in carrying out counseling based on the judge's order, must be implemented for convicts. Furthermore, related to software are the counseling curriculum, counseling programs that are curated and adjusted to the number and frequency and length of additional penalties imposed, re-programs for those 
who fail and or further processes if the convict does not meet the program, schedule and number of counseling curricula/scheduled.

The shell tools referred to here are the infrastructure and facilities that are needed and have been provided by the State through the SPP to carry out and implement counseling for convicts. The person in charge and manager of the infrastructure and facilities, accessibility, and affordability of the convict in fulfilling the judge's order that imposes an additional penalty in the form of an order to follow.

Furthermore, so that additional penalties in the form of orders for perpetrators of domestic violence crimes to attend counseling can be implemented properly, the study identifies and concludes two important requirements, namely juridical requirements, and sociological requirements. The juridical requirement is that the judge must order the defendant to attend counseling, either at his own expense or at the government's expense; where and how counseling is scheduled and implemented; who is the counselor (both private and government) who is responsible for providing counseling, the requirements to declare the success or failure of the counseling process. Before determining that the convict undergo counseling, the Judge needs to ensure and/or must be proven convincingly or at least it can be proven that the defendant only made a mistake, did not intend to cause physical and psychological suffering to the victim. In court proceedings, it is necessary to observe the motive or strong will of the perpetrator when do domestic violence; tools used to carry out domestic violence; modus operandi. Sociological requirements such as other things that accompany the behavior of domestic violence carried out by the perpetrator such as the presence of a third person who is more desirable than his current partner (victim), the victim's job, the job or profession he carries out in financing his life and family life, the perpetrator's income, family expenses, lifestyle and consumption patterns of the family, as well as the economic burden on the family borne by the perpetrator and/or other things that may prevent the perpetrator of domestic violence from being able to realize and regret his actions.

\section{ADVANTAGES AND DISADVANTAGES OF COUNSELING AS AN ADDITIONAL SENTENCE}

One of the important aspects to capture the urgency of imposing additional penalties by judges in the form of orders to attend counseling is an academic 
scientific study related to the advantages and disadvantages of the institution. For judges, the option to impose additional penalties in the form of orders to take counseling will only be chosen if on the one hand it creates a deterrent effect for the perpetrator and is a commensurate reward, the same as the perpetrator's actions. Likewise for the perpetrator, the desire to fulfill the counseling program imposed by the judge can only be chosen and followed if the perpetrator feels guilty and wants to return to repairing the disharmony condition in his family.

The study also identified that if the additional punishment in the form of an order for perpetrators of domestic violence to follow counseling can be imposed and carried out properly by the perpetrator, the family can be maintained, and children can be raised in a more conducive family atmosphere. For religious communities such as in Indonesia in general and in the Province of East Nusa Tenggara in particular, all efforts made to maintain the family are the greatest efforts that must be pursued. It should be noted that the family is the smallest community that is the main and inseparable part in building the nation and state community, so maintaining and strengthening the family institution is as serious as maintaining and strengthening the Indonesian nation and state community. The disadvantage is that the process is time consuming and requires the mobilization of more or more resources.

\section{CONCLUSION}

This study concluded and highlighted that additional punishment in the form of orders for perpetrators of domestic violence crimes to take counseling is intended so that the perpetrators can realize their actions, repent and or promise not to commit/commit violence again and return to a harmonious relationship with their wives and children to achieve their ideals of marriage. promised earlier. In order that additional punishment in the form of orders for perpetrators of domestic violence crimes to take counseling can be implemented properly, the study identifies and concludes two important requirements, namely juridical requirements, sociological requirements. The juridical requirement is that the judge must order the defendant to attend counseling, either at his own expense or at the government's expense; where and how counseling is scheduled and implemented; who is the counselor (both private and government) who is responsible for providing counseling, the requirements to declare the success or failure of the counseling process. Additional penalties in the form of orders for perpetrators of domestic violence crimes to follow counseling can be imposed 
and carried out properly by the perpetrators, so that families can be maintained, children can be raised in a more conducive family atmosphere. For religious communities such as in Indonesia in general and in the Province of East Nusa Tenggara in particular, all efforts made to maintain the family are the greatest efforts that must be pursued. It should be noted that the family is the smallest community that is the main and inseparable part in building the nation and state community, so maintaining and strengthening the family institution is as serious as maintaining and strengthening the Indonesian nation and state community. The disadvantage is that the process is time consuming and requires the mobilization of more fund or more resources. To facilitate the implementation of the Judge's decision which contains an order to take counseling as an additional decision it is recommended to recruit and train professional counselors who understand domestic issues, especially on the motives of the perpetrators, causes and reasons for domestic violence and are able to find and offer solutions for perpetrators of domestic violence crimes who are ordered to attend counseling as well as to Provide facilities and infrastructure as well as adequate programs and curriculum in implementing counseling for perpetrators of domestic violence.

\section{REFERENCES}

Ciciek, F. (2005). Jangan Ada Lagi Kekerasan dalam Rumah Tangga. Jakarta: Gramedia Pustaka Utama.

Garner, B. A. (ed). (1999). Black's Law Dictionary $8^{\text {th }}$ Editions. Thomson \& West. Garner, B. A. (ed). (2014). Black's Law Dictionary 10th Editions. West Group.

Katjasungkana, N., \& Damanik, A. (2004). Kejahatan yang Tak Dihukum: Studi Kasus Kekerasan Domestik. Jakarta: LBH Apik Jakarta.

Luhulima, A. (2000). Pemahaman Bentuk-Bentuk Kekerasan terhadap Perempuan dan Alternatif Pemecahannya. Jakarta: Kelompok Kerja "Convention Watch" Pusat Kajian Wanita dan Jender Universitas Indonesia.

Nurcahyo, L. I., \& Ramadhan, C. R. (2016). Kekerasan Terhadap Perempuan Dalam

Peradilan Pidana: Analisis Konsistensi Putusan. Jakarta: AIPJ, MaPPI FHUI, LBH APIK Jakarta.

Reinhardt, G., \& Cannon, A. (eds). "Australian Magistrates, Therapeutic Jurisprudence and Social Change - Transforming Legal Process in Court and Beyond," A Collection of Referred Papers from the 3rd International 
Conference on Therapeutic Jurisprudence, In iSharyn Roach Anleu and athy Mack, Perth, Western Australia 7-9 June 2006).

Soeroso, M. H. (2010). Kekerasan Dalam Rumah Tangga Dalam Perspektif YuridisViktimologis. Jakarta: Sinar Grafika.

Suhasril, S. (2016). Perlindungan Hukum Terhadap Anak dan Perempuan. Jakarta: Rajawali Press.

Tim Penulis Agupena. (2016). PAPPATAMMA: Perlindungan Perempuan dan Anak Berbasis Kearifan Lokal di Indonesia. Yogyakarta: Deepublish.

Wattie, A. M. (2002). Kekerasan terhadap Perempuan di Ruang Publik; Fakta, Penanganan dan Rekomendasi. Yogyakarta: PPK dan Ford Foundation.

Winick, B. J., \& Wexler, D. B. (eds). (2003). Judging in a Therapeutic Key: Therapeutic Jurisprudence and the Courts. Durham NC, Carolina: Academic Press.

\section{Legal Document}

Putusan Pengadilan Nomor 41/Pid.Sus/2015/PN.Rno - (BHT).( tanggal 20-012016).

Undang-undang Nomor 23 Tahun 2004 Tentang Penghapusan Kekerasan Dalam Rumah Tangga. 
"The guarantee of safety in a battering relationship can never be based upon a promise from the perpetrator, no matter how heartfelt. Rather, it must be based upon the self-protective capability of the victim. Until the victim has developed a detailed and realistic contingency plan and has demonstrated her ability to carry it out, she remains in danger of repeated abuse."

\section{Judith Lewis Herman}

Trauma and Recovery: The Aftermath of Violence

- From Domestic Abuse to Political Terror 